\title{
The Determinant of Non-Performing Financing on Micro, Small, and Medium Enterprises (MSME) Financing of Islamic Banking in Indonesia
}

\author{
Hayet $^{1}$, Eddy Suratman ${ }^{2}$ \\ hayet.hayet@ekonomi.untan.ac.id ${ }^{1}$,eddy.suratman@ekonomi.untan.ac.id ${ }^{2}$ \\ Universitas Tanjungpura, Pontianak ${ }^{12}$
}

\begin{abstract}
The financing provided by Islamic Banks in the Micro, Small, and Medium Enterprises (MSME) sector has a high risk of default. The purpose of this study was to determine the effect of inflation, economic growth, and the exchange rate on nonperforming financing (NPF) of the MSME financing sector of Islamic Banking in Indonesia during 2010-2019. This study uses secondary data (times series) with multiple linear regression analysis approaches. The partial test result shows that inflation has a positive and significant effect on the problematic financing of MSMEs. This was caused by an increase in inflation that occurred which led to an increase in MSME production costs. Economics growth has a negative and insignificant effect on MSME financing problems. Indonesia's economic growth is driven by the household consumption sector so it tends to have a less double impact on the economy. The exchange rate has a negative and significant effect on MSME financing problems. The depreciating rupiah exchange rate causes the price of MSME product to be cheaper in foreign markets which increases income from exports.
\end{abstract}

Keywords: Non-Performing Financing, Inflation, Economic Growth, and Exchange Rates

\section{Pendahuluan}

Non-performing financing (NPF) merupakan indikator penting untuk melihat kinerja bank syariah pada aspek kemampuan mengelola aset dan likuiditas serta memitigasi resiko yang dihadapi. Nilai NPF bergerak fluktuatif dan sulit dikontrol karena mengikuti perkembangan jumlah pembiayaan, tingkat pengembalian pembiayaan, dan kinerja perusahaan serta faktor internal dan eskternal lainnya. Rasio NPF digunakan untuk mengukur resiko kegagalan dari pembiayaan dengan menghitung jumlah pembiayaan bermasalah (kategori pembiayaan yang terdiri dari macet, diragukan dan kurang lancar) terhadap total keseluruhan pembiayaan yang diberikan[1].

Pembiayaan yang diberikan oleh bank syariah kepada sektor usaha kategori mikro, kecil dan menengah (UMKM) menghadapi resiko yang lebih besar dibandingkan sektor Menengah dan Atas. Sektor UMKM umumnya merupakan usaha (industri) skala rumahan (homemade) dengan keterbatasan modal, bahan baku, jumlah produksi hingga pemasaran produk. Namun peran UMKM telah menjadi tulang punggung perekonomian nasional dengan kontribusi sebesar 57,08\% terhadap total PDB tahun 2017. Serapan tenaga kerja mencapai 116.674 .416 orang atau sebesar 97,02\%. Jumlah usaha mikro mencapai $98,70 \%$, kemudian uaha kecil sebesar $1,20 \%$ dan usaha menengah sebesar $0,09 \%$. Perkembangan rasio NPF perbankan syariah di Indonesia mengalami tren peningkatan yang mengindikasikan resiko gagal bayar yang semakin tinggi. Pada tahun 
2014, rasio NPF menunjukkan angka tertinggi dengan nilai 3,2\%. Berikut data pertumbuhan ekonomi, inflasi, nilai tukar dan NPF di Indonesia pada tahun 2010 - 2018.

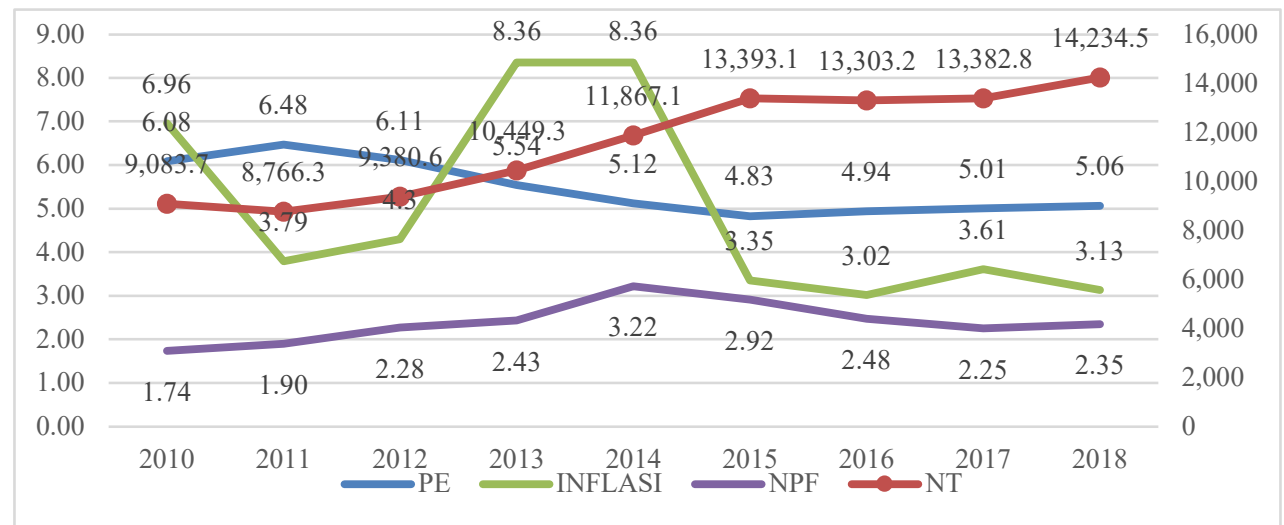

Gambar 1 Data Pertumbuhan Ekonomi, Inflasi, Nilai Tukar dan NPF di Indonesia Tahun 2010-2018 Sumber : The Global Economic, Otoritas Jasa Keuangan (OJK)

Secara empiris, peningkatan rasio pembiayaan bermasalah yang dialami oleh perbankan bisa sebabkan oleh faktor internal yang berkaitan manajerial dan operasional bank tersebut maupun faktor eksternal. Pengaruh faktor eskternal secara umum berkaitan dengan situasi dan perkembangan ekonomi secara keseluruhan seperti laju inflasi, proyeksi pertumbuhan ekonomi, stabilitas nilai tukar, kemudahan investasi, serta situasi bisnis secara keseluruhan. Erdinç \& Abazi, menyatakan dinamika pembiayaan bermasalah (NPL) sangat sensitif dipengaruhi oleh pertumbuhan PDB rill dan inflasi[2], sedangkan Rahmawulan menyebutkan bahwa pembiayaan bermasalah sangat dipengaruhi oleh GDP yang memiliki hubungan yang positif[3]. Skarica menyatakan perlambatan ekonomi yang ditunjukan dengan perubahan koefisien PDB yang negatif, pengangguran dan tingkat inflasi[4]. Wikutama menjelaskan bahwa secara umum inflasi tidak siginifikan berdampak pada perubahan NPL[5].

Penelitian yang dilakukan Zainol menyebutkan bahwa variabel makro ekonomi yang mempengaruhi NPF pada bank syariah di Malaysia yaitu industrial production index, income rate dan producer price index[6]. Adapun perubahan nilai tukar menurut Soebagio akan menyebabkan perubahan rasio kredit bermasalah yang cukup signifikan seperti halnya yang terjadi pada bank umum komersial di Indonesia[7].

\section{Kajian Literatur}

Antonio[25] menjelaskan bahwa resiko pembiayaan akan muncul jika bank syariah tidak mendapatkan kembali angsuran pokok, dan profit atau bagi hasil usaha atas pinjaman yang diberikan kepada debitur atau nasabah. Kerugian yang ditimbulkan akibat resiko pembiayaan tercermin dari besarnya indikator rasio permbiayaan bermasalah atau non performing financing (NPF). Rasio NPF dihitung dari jumlah total pembiayaan bermasalah (katergori kriteria pembiayaan macet, diragukan dan kurang lancar) terhadap keseluruhan pembiayaan yang disalurkan oleh bank syariah. Pembiayaan sektor UMKM adalah pinjaman yang diberikan kepada debitur kategori usaha, kecil dan menengah baik perorangan maupun perusahaan sesuai 
dengan definisi dan kriteria UU No. 2 Tahun 2008 tentang UMKM. Pembiayaan sektor UMKM memiliki resiko dan kerentanan gagal bayar yang tinggi mengingat karakteristik UMKM yang memiliki modal yang terbatas, pengalaman menejerial yang lemah, skala ekonomi terlalu kecil, dan persaingan yang sangat kompetitif.

Siamat (2009)[26] menjelaskan bahwa terdapat berbagai faktor internal dan eksternal yang mempengaruhi tingginya rasio kredit bermasalah. Adapun faktor eksternal dapat disebabkan oleh penurunan kegiatan ekonomi, kegagalan usaha debitur, persaingan perbankan yang tidak sehat, terjadi bencana alam. Indikasi pembiayaan bermasalah dapat diketahui dari prilaku kegiatan bisnis, prilaku nasabah dan prilaku makroekonomi. Perubahan pasar yang begitu cepat seperti perubahan nilai tukar, tingkat suku bunga, dan inflasi akan mendorong peningkatan terjadinya pembiayaan bermasalah.

\section{Faktor Ekonomi Non Performing Financing Perbankan Syariah}

Tinjuan literatur dan kajian empiris menemukan bahwa kenaikan inflasi memiliki korelasi negatif negatif terhadap perkembangan NPF. Beberapa hasil penelitian yang dilakukan oleh Effendi, Thiarany dan Nurmasyah (2017)[8]; Popita (2013)[9]; Mutamimah dan Chasanah (2012)[1]; Santoso Siregar dan Hakim (20019)[10]; dan Firmasyah (2015)[11] mengungkap fakta tersebut. Inflasi yang tidak terkendali memberikan dampak yang negatif terhadap perkembangan ekonomi dan sosial masyarakat. Kenaikan inflasi yang tinggi mendorong penurunan pendapatan riil masyarakat, memberikan ketidakpastian kepada pelaku ekonomi, terjadi kenaikan biaya produksi yang disebabkan kenaikan bahan baku, dan tingkat suku bunga menjadi tidak kompetitif meskipun bank syariah tidak berdasarkan standar bunga. Hal tersebut mempengaruhi kemampuan debitur dalam membayar kewajiban pembiayaan kepada bank syariah secara langsung maupun tidak langsung.

Pertumbuhan ekonomi memberikan pengaruh terhadap penurunan pembiayaan bermasalah. Hasan dan Bashir (2005)[12] menemukan bahwa kondisi makro ekonomi memberikan pengaruh terhadap kinerja bank syariah. Pertumbuhan ekonomi merupakan kenaikan output produksi dari berbagai faktor produksi secara agregat yang mengindikasikan terjadi kenaikan pendapatan serta menujukkan kondisi bisnis yang kondusif. Penelitian yang dilakukan oleh Abduh dan Alias (2014)[13] menemukan hubungan yang positif terhadap NPF, sedangkan Izzati dan Aziz (2017)[14] menemukan bahwa pertumbuhan ekonomi melalu kenaikan GDP memiliki hubungan yang negatif dan tidak signfikan pada bank syariah. Sedangkan keterkaitan pertumbuhan ekonomi terhadap resiko pengembalian kridit menunjukkan pengaruh yang positif dan signifikan menurut Zheng dkk (2019)[15]; Jordan (2013) [16]; Mazreku dkk (2018) [17] dan Klein (2013)[18]. Kenaikan pertumbuhan ekonomi, akan meningkatkan pendapatan perkapita masyarakat, kemudiian diikuti peningkatan daya beli, serta kenaikan produksi dan pendapatan debitur.

Perubahan nilai tukar dapat memberikan dampak yang negatif dan positif terhadap perekonomian, namun fluktuasi nilai tukar yang tinggi akan meningkat resiko pasar yang dihadapi bank syariah. Penelitian yang dilakukan oleh Vanni dan Rokhman (2018)[19]; dan Mohamadi [20]; Hernawati dan Puspasari (2018) [21] menyatakan bahwa nilai tukar berpengaruh pada pembiayaan bermasalah. Hasil penelitian yang berbeda ditunjukkan oleh Indrajaya 
(2019)[22] yang menyebutkan bahwa nilai tukar tidak memiliki korelasi terhadap perubahan NPF bank umum syariah. Fluktuasi nilai tukar akan mempengaruhi ekspor dan impor. Apabila rupiah mengalami depresiasi akan mendorong kenaikan biaya produksi bahan baku dan pembiayaa impor. Situasi ini menyebabkan debitur mengalami penurunan pendapatan yang berakibat pada gagal bayar kepada perbankan.

\section{Metode Penelitian}

Metodologi penelitian ini menggunakan pendekatan kuantitatif ekperimental yang menggunakan data statistik yang diperlukan dalam pengujian hipotesis. Adapun populasi dalam penelitian ini adalah keseluruh perbankan syariah di Indonesia yang terdiri dari BUS, UUS dan BPRS yang tercatat dalam laporan Otoritas Jaa Keuangan dan Bank Indonesia. Variabel terikat (dependen) adalah NPF sektor pembiayaan UMKM pada perbankan syariah, sedangan variabel makro ekonomi sebagai variabel besar adalah inflasi, pertumbuhan ekonomi dan nilai tukar. Data sekunder yang gunakan bersifat time series berbentuk data triwulanan selama periode 2010-2019.

Model yang digunakan dalam penelitian ini menggunkan estimasi times series, sebelum menguji terlebih dahulu dilakukan uji asumsi klasik berupa unit root test yang diperlukan untuk mengetahui apakah data stationer pada tingkat level atau pada first difference dengan menggunakan metode Aumented Dicky Fuller Test (Tes ADF). Robustness test (heterokedasticity test, multikolinearity test dan autocorrelation test) diperlukan untuk memenuhi syarat pada model regresi linier untuk memastikan validitas model tersebut. Terakhir akan dilakukan uji regresi linear berganda untuk mengukur intensitas hubungan antar vaiabel dan membuat model prediksi perkiraan nilai $\mathrm{Y}$ atas $\mathrm{X}$. Model regresi secara sederhana sebagai berikut:

$$
Y=a+\beta 1 X_{1}+\beta 2 X_{2}+B 3 \beta 1 X_{3}+\varepsilon
$$

dimana :

$\mathrm{Y} \quad=\mathrm{NPF}$

$X_{1} \quad=$ Inflasi

$X_{2} \quad=$ Nilai Tukar

$X_{3} \quad=$ Pertumbuhan Ekonomi

$\beta=$ parameter koefisien regresi

\section{Hasil Penelitian Dan Pembahasan}

Hasil uji stationer pada tingkat first difference, maka dapat diketahui bahwa seluruh variabal lolos pada uji level baik menggunakan metode Augmented Dickey - Fuller. Hal ini ditunjukkan dengan nilai probabilitas $<0,05$. Berdasarkan ui heteroskedastisitas dengan menggunkan metode Glejser diperoleh nilai Obs*R-squared sebesar 3.968028 dan nilai Prob. Chi-Square sebesar 0,2649 >0,04. Dengan angka tersebut menunjukkan bahwa tidak terjadi heteroskedastisitas. Berdasarkan pengujian Breusch-Godfrey menunjukkan bahwa Obs*RSquare sebesar 0,0550693 dan nila Prob. Chi-Square bernilai 0,0793 $>0,05$ sehingga dapat dikatakan bahwa tidak terjadi autokorelasi. Hasil pengujian regresi sebagai berikut: 


$$
N P F=3,576069+0,000135 \operatorname{Inf}-0,037245 N t-0,000299 P e .
$$

Hasil penelitian ini mengkonfirmasi bahwa inflasi yang terjadi di Indonesia berpengaruh positif dan signifikan terhadap peningkatan rasio permbiayaan bermasalah pada sektor UMKM di perbankan syariah. Berdasarkan data dari BPS dari selama periode 2010-2018, faktor terbesar yang menyebabkan terjadinya inflasi adalah sektor kelompok bahan makanan dengan angka tertinggi pada tahun 2010 sebesar 16,35\% sehingga terjadi kenaikan harga bahan baku produksi. Penyebab kedua yang sangat mempengaruhi inflasi adalah sektor transportasi, komunikasi dan jasa keuangan dengan angka 15,36\% tingginya harga tiket angkutan udara menjadi salah satu faktor terjadinya inflasi pada tahun 2015. Tingginya inflasi di kedua sektor tersebut menyebabkan biaya produksi dalam negeri meningkat, akan tetapi peningkatan tersebut tidak diiringi dengan peningkatan penjualan dan penyesuaian harga sehingga menyebabkan daya beli menurun dan pendapatan dari keuntungan juga mengalami penurunan. Kondisi tersebut mengakibatkan debitur mengalami kesulitan membayar kewajiban yang telah disepakati pada saat akad dilakukan. Faktor lain yang menyebabkan para pelaku UMKM terlambat membayar kewajibannya, yaitu faktor sosial yang mempengaruhi biaya produksi dan distribusi (cost-push inflation). Adapun permasahan pelaku UMKM diantara pengelolaan infrastruktur, akses terhadap lahan, biaya transaksi, izin usaha, dan kondisi kemanan serta penyelesaian sengketa [23]. Penelitian ini menguatkan hasil penelitian sebelumnya yang dilakukan oleh Effendi, Thiarany dan Nurmasyah (2017), Popita (2013), Mutamimah dan Chasanah (2012), Santoso Siregar dan Hakim (2019); dan Firmasyah (2015).

Tabel 1. Hasil Uji Parsial

\begin{tabular}{|l|c|c|c|}
\hline \multicolumn{1}{|c|}{ Variable } & t-Statistic & Prob. & Keterangan \\
\hline Inflasi & 2.714151 & 0.0104 & Signifikan \\
\hline Nilai Tukar & -2.973095 & 0.0054 & Signifikan \\
\hline Pertumbuhan Ekonomi & -1.979138 & 0.0559 & Tidak Signifikan \\
\hline
\end{tabular}

Sumber : Olahan data

Pengaruh pertumbuhan ekonomi yang terjadi di Indonesia memberikan dampak yang negatif dan tidak signifikan terhadap NPF pembiayaan sektor UMKM perbankan syariah. Pertumbuhan ekonomi merupakan cerminan peningkatan produksi barang dan jasa sekaligus indikator optimisme kalangan dunia usaha. Semakin tinggi pertumbuhan ekonomi, akan mendorong peningkatan permintaan secara agregat dan peningkatan pendapatan UMKM. Variabel pertumbuhan ekonomi tidak signifikan terhadap NPF disebabkan oleh pertumbuhan ekonomi di Indonesia digerakkan oleh konsumsi sektor rumah tangga dengan kontribusi sebesar $56,04 \%$ dari total PDF. Disisi lain terjadi defisit neraca perdagangan yang ditandai dengan nilai impor yang meningkat terhadap nilai ekspor barang dan jasa sejak tahun 2012. Bahkan beberapa sektor industri sepenuhnya mengandakan impor. Situasi ini memberikan tekanan terhadap peningkatan produksi dan cenderung mematikan pelaku usaha dan industri di dalam negeri khususnya pelaku UMKM. Hasil penelitian ini menguatkan penelitian yang dilakukan oleh Izzati dan Aziz (2017) bahwa pertumbuhan ekonomi cenderung memiliki korelasi yang negatif terhadap pembiayaan bermasalah di perbankan syariah. 
Pengaruh nilai tukar rupiah memiliki hubungan yang negatif dan signifikan terhadap NPF sektor UMKM perbankan syariah. Depresiasi nilai tukar rupiah mendorong penurunan resiko gagal bayar pembiayaan UMKM yang diberikan oleh bank syariah. Depresiasi nilai tukar terhadap dollar menyebabkan harga produk dalam negeri menjadi lebih kompetitif sehingga akan meningkatkan permintaan barang dari luar negari. Disisi lain, debitur bank syariah sektor UMKM sebagian menggunakan bahan baku lokal dalam aktifitas produksi sehingga tidak memiliki keterkaitan langsung terhadap perubahan kurs. Hasil penelitian ini menguatkan bahwa Vanni dan Rokhman (2018); dan Mohamadi; Hernawati dan Puspasari (2018). Terdepresiasi rupiah terhadap mata uang asing memang menimbulkan capital outflow atau pengalihan modal oleh investor ke luar negari yang berdampak negatif terhadap perekonomian, namun hal tersebut terjadi dalam siatuasi jangka pendek dan tidak berpengaruh terhadap sektor UMKM. Nilai koefisien determinasi $\mathrm{R}^{2}$ sebesar 43,79 persen. Perkembangan pertumbuhan ekonomi, laju inflasi serta fluktuasi nilai tukar secara bersamaan menunjukkan pengaruh yang kuat dan signifikan terhadap kenaikan rasio pembiayaan bermasalah.

\section{Kesimpulan}

Hasil penelitian ini menemukan bahwa laju inflasi yang terjadi di Indonesia memiliki korelasi yang positif dan signifikan terhadap peningkatan rasio pembiayaan bermasalah (NPF) pada sektor UMKM pada perbankan syariah. Sementara laju pertumbuhan ekonomi cenderung mengurangi rasio NPF meskipun memiliki korelasi yang sangat lemah dan tidak signifikan. Sedangkan perubahan nilai tukar rupiah memberikan dampak yang positif terhadap penurunan rasio NPF dengan korelasi yang cukup kuat (negatif dan signifikan). Hubungan inflasi, pertumbuhan ekonomi dan nilai tukar secara bersama-sama berpengaruh terhadap NPF sektor UMKM di Indonesia.

\section{References}

[1] S. Mutamimah and N. Z. Chasanah, "Analisis Eksternal Dan Internal Dalam Menentukan Non Performing Financing Bank Umum Syariah Di Indonesia,” J. Bisnis dan Ekon., vol. 19, no. 1, pp. 49-64, 2012.

[2] D. ERDİNÇ and E. ABAZİ, "The Determinants of NPLs in Emerging Europe, 2000-2011," J. Econ. Polit. Econ., vol. 1, no. 2, pp. 112-125, 2014, doi: 10.1453/JEPE.V1I2.59.

[3] Y. Rahmawulan, "Perbandingan Faktor Penyebab Timbulnya NPL dan NPF Pada Perbankan Konvensional dan Syariah di Indonesia," no. April, 2008.

[4] B. Skarica, "Determinants of non-performing loans in Central and Eastern European countries," Financ. Theory Pract., vol. 38, no. 1, pp. 37-59, 2014, doi: 10.3326/fintp.38.1.2.

[5] A. Wikutama, "Universitas Indonesia Faktor-Faktor Yang Mempengaruhi Non Performing Loan Bank Pembangunan Daerah ( Bpd ) Tesis,” pp. 1-12, 2010.

[6] J. M. Zainol, A. M. Nor, S. N. Ibrahim, and S. Daud, "Macroeconomics Determinants of NonPerforming Loans in Malaysia: An ARDL Approach," Int. J. Acad. Res. Bus. Soc. Sci., vol. 8, no. 10, 2018, doi: 10.6007/ijarbss/v8-i10/4773.

[7] H. Soebagio, “Analisis Faktor-Faktor yang Mempengaruhi Terjadinya Non Performing Loan (NPL) pada Bank Umum Komersial (Studi Empiris pad di Indonesia).” 2005. 
[8] J. Effendi, U. Thiarany, and T. Nursyamsiah, "Factors Influencing Non-Performing Financing (NPF) at Sharia Banking," Walisongo J. Penelit. Sos. Keagamaan, vol. 25, no. 1, p. 109, 2017 , doi: $10.21580 /$ ws.25.1.1540.

[9] M. S. A. Popita, "Analisis Penyebab Terjadinya Non Performing Financing Pada Bank Umum Syariah Di Indonesia," Account. Anal. J., vol. 2, no. 4, pp. 404-412, 2013, doi: 10.15294/aaj.v2i4.2884.

[10] M. H. Santoso, H. Siregar, D. B. Hakim, and M. E. Siregar, "DETERMINANTS OF ISLAMIC BANK NON-PERFORMING FINANCING BY FINANCING CONTRACT ( CASE STUDY : BANK BRI SYARIAH PRIVATE COMPANY ) Sharia banking as one preferred banking system in," vol. 5, no. 1, pp. 77-86, 2019.

[11] I. Firmansyah, "Determinant of Non Performing Loan: the Case of Islamic Bank in Indonesia," Bul. Ekon. Monet. dan Perbank., vol. 17, no. 2, pp. 241-258, 2015, doi: 10.21098/bemp.v17i2.51.

[12] K. Hasan and H. Bashir, "Determinan of Islamic Bank Profitability,” ERF Annu. Conf., 2005.

[13] M. Abduh and A. Alias, "Factors Determine Islamic Banking Performance in Malaysia: A Multiple Regression Approach,” J. Islam. Bank. Financ., pp. 44-54, 2014.

[14] N. O. R. Izzati and M. Aziz, "Islamic Banking Profitability: Roles played by Internal and External Banking Factors," J. Muamalat Islam. Financ. Res., vol. 14, no. 1, pp. 23-38, 2017.

[15] C. Zheng, P. K. Bhowmik, and N. Sarker, "Industry-Specific and Macroeconomic Determinants of Non-Performing Loans: A Comparative Analysis of ARDL and VECM," Sustainability, vol. 12 , no. 1 , p. 325 , 2019, doi: 10.3390/su12010325.

[16] A. Jordan, "Assessing the Impact of Nonperforming Loans on Economic Growth in The Bahamas," Monet. (English Ed., vol. I, no. 2, pp. 371-400, 2013.

[17] I. Mazreku, F. Morina, V. Misiri, J. V. Spiteri, and S. Grima, "Determinants of the level of nonperforming loans in commercial banks of transition countries," Eur. Res. Stud. J., vol. 21, no. 3, pp. 3-13, 2018, doi: 10.35808/ersj/1040.

[18] N. Klein, "Non-Performing Loans in CESEE: Determinants and Impact on Macroeconomic Performance," IMF Work. Pap., vol. 13, no. 72, p. 1, 2013, doi: 10.5089/9781484318522.001.

[19] K. M. Vanni and W. Rokhman, "Analisis Faktor-Faktor Yang Mempengaruhi Non Performing Financing Pada Perbankan Syariah Di Indonesia Tahun 2011-2016," Equilib. J. Ekon. Syariah, vol. 5, no. 2, p. 306, 2018, doi: 10.21043/equilibrium.v5i2.2776.

[20] D. Mohamadi, Teimur; Shakeri, Abbas; Eskandari, Farzad; Karimi, "The Effect of Exchange Rate Volatility on Non-performing Loans in the Banking System of Iran," J. Plan. Budg., vol. 21, no. 2, pp. 3-24, 2016.

[21] H. Hernawati and O. R. Puspasari, "Pengaruh Faktor Makroekonomi terhadap Pembiayaan Bermasalah,” J. Islam. Financ. Account., vol. 1, no. 1, 2018, doi: 10.22515/jifa.v1i1.1134.

[22] Indrajaya, "Determinan Non-Performing Financing," pp. 68-81, 2019.

[23] KPPOD, “Tata Kelola Ekonomi Daerah 2016,” 2016.

[24] D. C. N. Syahid, "Pengaruh Faktor Eksternal dan Internal Terhadap Kredit Bermasalah serta Dampaknya Terhadap Cadangan Kerugian Penurunan Nilai Menurut PSAK 55," J. Perbanas, vol. 2, no. 1, pp. 1-23, 2016, doi: 10.1016/s0957-4174(99)00061-5.

[25] M. S. Antonio, Bank Syariah dari Teori ke Praktik, Jakarta: Gema Insani, 2001

[26] D. Siamat, Manajemen Lembaga Keuangan, Yogyakarta: PT. Dwi Chanda Wacana, 2005. 